【解説】

\title{
高温液体の熱物性值
}

\author{
長島 昭 \\ 慶応義塾大学理工学部 \\ 干223 横浜市港北区日吉 $3-14-1$
}

\begin{abstract}
最近、単結晶製造などの工学的必要性と、液体構造など科学的重要性の両方の興味から、 高温の液体、なかでも高温の融体の熱物性值を詳しく知ることが必要となっている。高温 の融体とは液体金属、溶融塩、溶融半導体などを指すが、これらに特有の実験的な難しさ と、現在のデータの問題点について述べる。
\end{abstract}

1.はじめに

最近、高温の液体の熱物性データが特に必要とされ るようになったのは、工業的応用の範囲が広がるばか りでなく、液体の流動状態などの従来にない微妙な制 蓹が必要となっているからである。

表 1 にも例を示すように、先端技術に用いられる液 体の種類も物性值も多侎である。高温液体には通常 の液体ばかりでなく、液体金属や溶融塩のように常温 では固体であって高温ではじめて液体となるものがあ る。それらの多くは、例えば化学的に活性で、興味深 い工策的応用がある反面、强い腐食性のため使える容 器材料に制約があり、酸化を避けるために雾囲気制御 が必要である。さらに、強い電気的活性のためにセン サーゃヒーターの絶縁が極めて難しい。したがって、 実駼的測定は一般に極めて困難である。これまでの测 定技術では測れない場合も多い。溶融状態のガラスや 高分子材料のように、比較的取扱いの容易な物貿であ っても、高温であるというだけで難しい。高温におい て気体や固体でなく、液体状態にあるということは、 伝热媒体としても倕れた性筫を持つということである が、その場合、熱物性值は、比熟、热伝導率など測定 の難しいものが必要になる。

しかし、このように必要でありながら測定のむすかか しい物質は、研究者から見れば非常に興味深い挑戦の 対象である。工学的な興味ばかりでなく、科学研究の 観点からも面白い課題が多い。例えば、融点近くにお ける高温の融体では、固体のみならず液体にも構造が 認められる。結晶成長の研究は融体および固体の物性 の情報が基礎となる。地球物理学では溶融岩石の物性 値がシミュレーション計算に必要である。

高温の虽体の熱物性值を特に扱つた調查としては、例 えば日本学術振興会第 140 委員会によるスラグの熱 物性值 [1]、鉄銅協会の委員会によるスラグと溶融 塩の熱物性値 [2、3] あるいはまた、溶融塩熱技術 研究会による特定の溶融塩のデー夕収集 [4、5 ] な
どの例がある。後に触れるように、文部省科学研究費 によって高温融体の熱物性值の測定技術の総合研究も 行われた [6]。データブックとしては、多くの测定 值がソ連で発表された関係上、ソ連の本が多かったが、 その他の最近の本では、0hseらによるアルカリ金属の データブック [7] などが注目に值する。

ここでは、限られた紙面ではあるが、高温の触体の 特に熱伝導率、粘性率、表面張力を中心として、最近 の研究やデー夕の現状について触れてみる。

$$
\text { 2. シミュレーション計算と熱物性值 }
$$

その前に、高温融体の熟物性值がどのような使われ 方至するか考えて、必要なデー夕の種類や、温度範囲、 必要精度などを想定する手がかりとする。高温融体あ るいは高温の液体を报うのは、工業的にも研究的にも

Table 1 高温液体の応用で必要な热物性值の例

\begin{tabular}{|c|c|c|}
\hline 半導体単結晶製造 & 半導体融体 & $\begin{array}{l}\text { 融点 } \\
\text { 表面張力 } \\
\text { 熱伝真率 } \\
\text { 粘性率 }\end{array}$ \\
\hline 高温燃料電池 & 溶融炭酸塩 & 熱伝導率 \\
\hline 高温箇熱技術 & 溶融塩 & $\begin{array}{l}\text { 融解潜熱 } \\
\text { 融点 }\end{array}$ \\
\hline 高分子材料 & 高分子融体 & $\begin{array}{l}\text { 軟化点 } \\
\text { 熹伝尊率 }\end{array}$ \\
\hline 核融合炉、高温炉 & $\begin{array}{l}\text { 冷却材 } \\
\text { ナトリウム } \\
\text { 搆造材 }\end{array}$ & $\begin{array}{l}\text { 比熱 } \\
\text { 粘性率 } \\
\text { 融点 }\end{array}$ \\
\hline 治金、製鋁 & $\begin{array}{l}\text { 溶融金属、 } \\
\text { スラグ }\end{array}$ & $\begin{array}{l}\text { 粘性率 } \\
\text { 融点 }\end{array}$ \\
\hline 高温超伝尊体製造 & 酸化物融体 & $\begin{array}{l}\text { 比熱 } \\
\text { 熱伝遵率 }\end{array}$ \\
\hline
\end{tabular}


装置が大がかりで高価なものとなり、試行をたびたび 行うわけにはいかない。したがって、シミュレーショ ンによる試行錯虽が特に重要な手法となる。ここでは システム設計のためのシミュレーションを指すが、ま ったく別の観点からの問題としては、分子挙動などの シミュレーションなどがある。シミュレーションでは 熱物性值データの信頼性によってその結果が大きく左 右される。高温融体については、特にこのようなニー ズを念頭において、データべースを整えてゆかなくて はならない。

一方では熱物性值の測定技術においても、シミュレ ーション計算は重要であり、例えば二次的な対流など の熟差要因の推定や、対流抑制などの対策に威力を発 揮する。液体の熱伝導率の測定では、最も大きな誤差 要因は熱対流の発生である。高温では、これを完全に 避けることは極めて難しいが、磁埸による力などを利 用して対流を抑え込む方法が考えられる。Fig，1 に示すのは、尾添ら［８］による計算例で、高温融体 の热伝導率測定のセルを想定して、垂直な 2 枚の平板 の間に液体が充たされている。それそれの条件下で、 等温線（左）と流れ関数（右）が表されている。左側 の壁面がかなり強く加热された埸合でも、対流による 温度場の乱れを、磁場によって抑制できることを示し ている。ここでRaはレイリー数で、加热の不均一によ る対流の起こり易さを表し、Haはハルトマン数で磁埸 による抑制勃果を表す。

実際に高温の虽体の热伝導率の測定において、日比 谷ら [9] は磁場の强さと対流抑制との関係を実験的 にも研究している。これらはいすれも熱伝導率の測定 を直接の目的としているが、もちろん単結晶製造の流 れ埸の制御などにも応用できる。

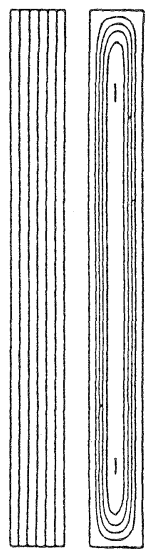

(a)

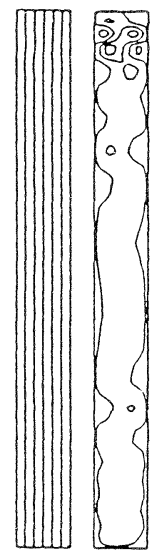

(c) (d)

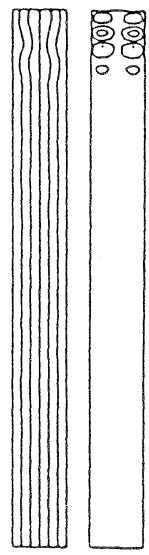

(e) (f)

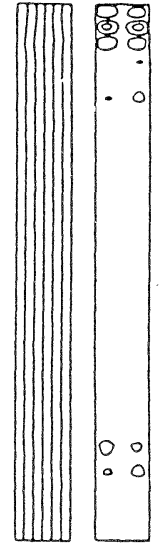

(g) (h) (i) (j)

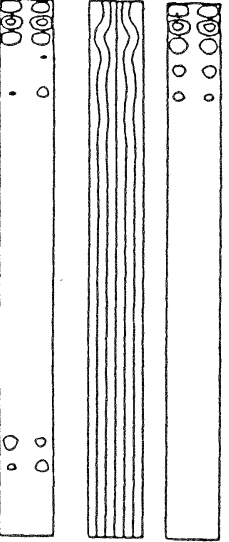
(a) Isotherms (b)
(e)
(d)
(8)
(i)
(f)
(j)
(k)
(1)

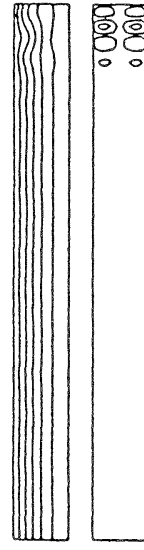

(k) (1)

\section{3. 高温融体の熱伝導率}

高温の虽体の熱物性值のうちで、デー夕が量的にも 筫的にも最も不備なのは熱伝導率である。Fig，2 に示すのは塩化ナトリウムの熱伝導率である。入手で きる限られたデー夕間には著しい不一致が珰められ、 その測定法さえ確立されていなかったことがわかる。 以前の測定者間には300\%ないし $400 \%$ にの泳る不一致 があり、しかも著者ら［1０］による最近の1例のみ を除いて、以前の測定例はいずれも强い正の温度依存 性を示している。著者らの測定では光学的非接触な方 法を用い、しかも 1 回の測定が $1 \mathrm{~ms}$ 程度で終了してい ることから、高温の液体で最も問題となる対流などの 誤差の可能性は小さいものと考えられる。また、他の ほとんど全ての液体では、熱伝導率の温度依存性が負 であることから、溶虽塩のみが强い正の温度依存性を 持つことは考えにくい。

ここで強調したいことは、塩化ナトリウムについて 見られるような、湖定者間のデー夕の不一致の特徵は、 ほとんどの他の溶融塩や液体金属などの熱伝導率デー 夕にも共通しているということである。この点を明ら かにした最近の興味深い研究は、溶融塩の熱伝導率の 温度依存性が、測定時の輻射の影響を補正するかどう

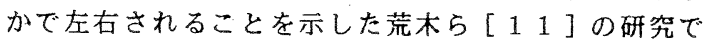
ある。Fig．３のように、輻射補正を加えると熱伝 導率は弱い負の温度依存性を示すようになる。高温の 伝熱シスデムでは、全伝熱量にしめる輻射伝热量のウ エイトがかなり大きいので、荒木らの方法で補正を加 えるならば、他の多くの溶融塩のデータも負の温度低 存性を示すようになる可能性がある。

もつと常温に近い温度範囲でも、従来の研究による

Fig. 1 Thermal convection in the magnetic field fluid confined in two vertical flat plates (finite height) (Figure by H.Ozoe et a 1. [8] ) 


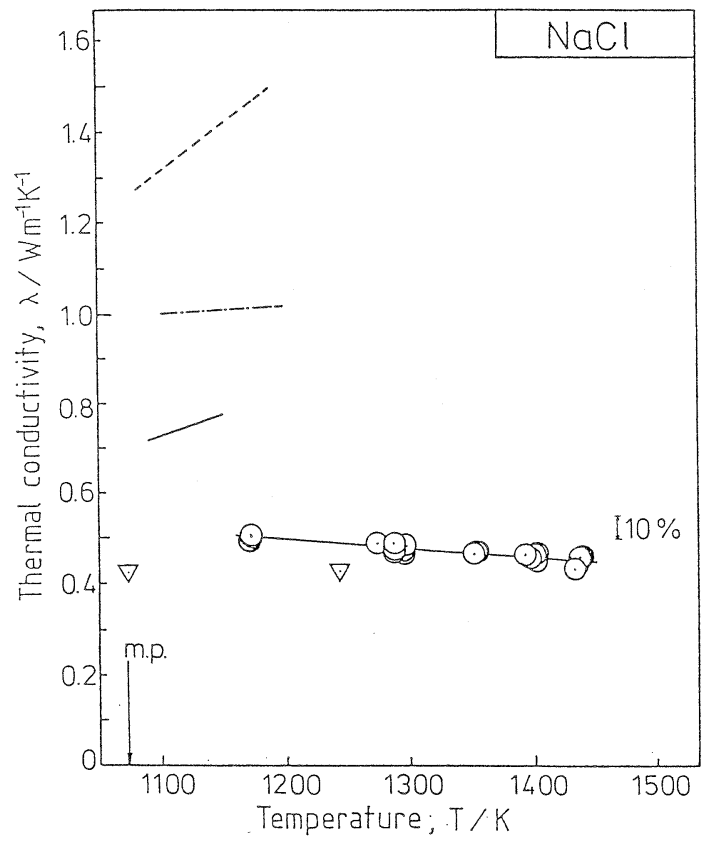

-.-Bystrai et al.(1976) - Smirnov et al. (1987)

---Fedorov ef al. (1970): $\nabla$ Golyshev ef al. (1983, - Nakazawa et al.(1990)

Fig. 2 Thermal conductivity of $\mathrm{NaCl}$

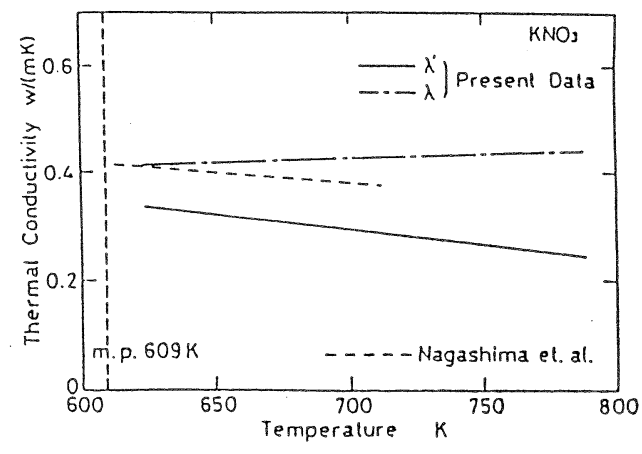

Fig. 3 Thermal conductivity of $\mathrm{KNO}_{3}$ by the stepwise heating method $\lambda^{\prime}$ corrected for thermal radiation $\lambda$ uncorrected (Figure by N.Araki et al. [11])

熱伝導率データの混乱した状態は、似たような状況に ある。Fig，4に示すのは、中間的な温度域での熱 媒体としてよく使われる硝酸ナトリウムの热伝道率で ある。ほとんどの過去の測定が正の温度低存性を示す 中で、最近の 2 例のみ、すなわち、光学的な非定常法 （黒丸）と試料層厚さを非常に薄く設定した円筒法 （下向き三角）が水平、またはゆるやかな負の温度依 存性を示している $\left[\begin{array}{ll}1 & 2\end{array}\right]$ 。また温度依存性のみでな く、組成依存性については、例えばFig．５に示す のは、硝酸ナトリウムと硝酸カリウムの混合系の熱伝 導率である。混合比に対し直線的に変化するMCDonald

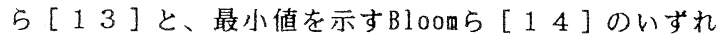
が正しいかは、かねてからの疑問であった。この問題 を明らかにするために、重谷らは特殊な非定常細線法 による測定を実施したが、MCDonaldらの方に軍配を上

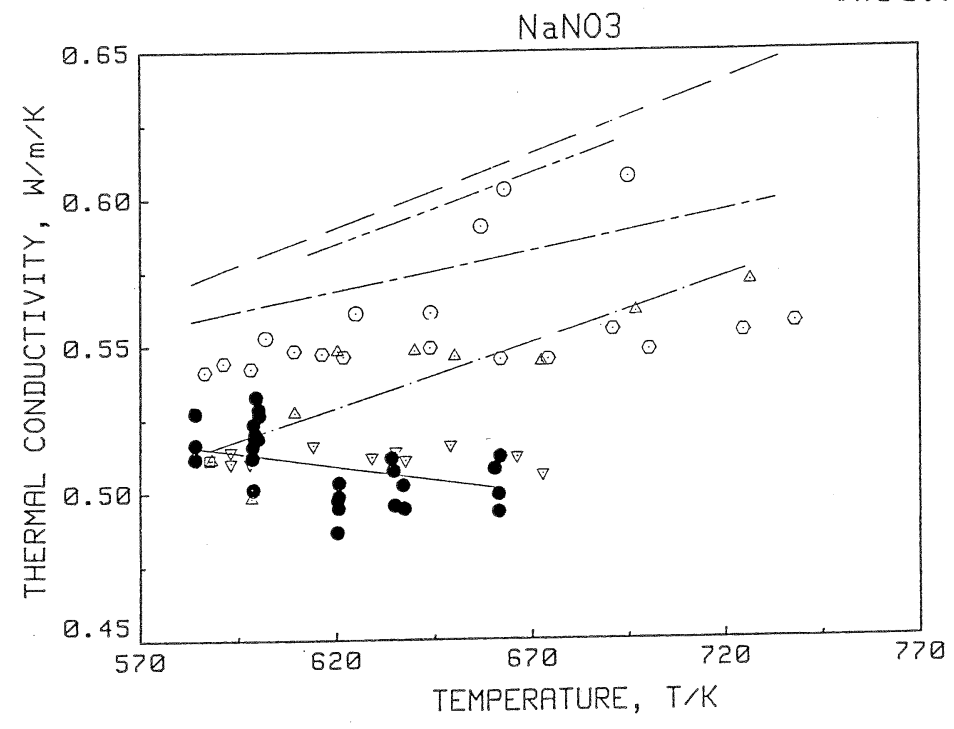

Fig. 4 Thermal conductivity of $\mathrm{NaNO}_{3}$ - Comparison of temperature dependences 


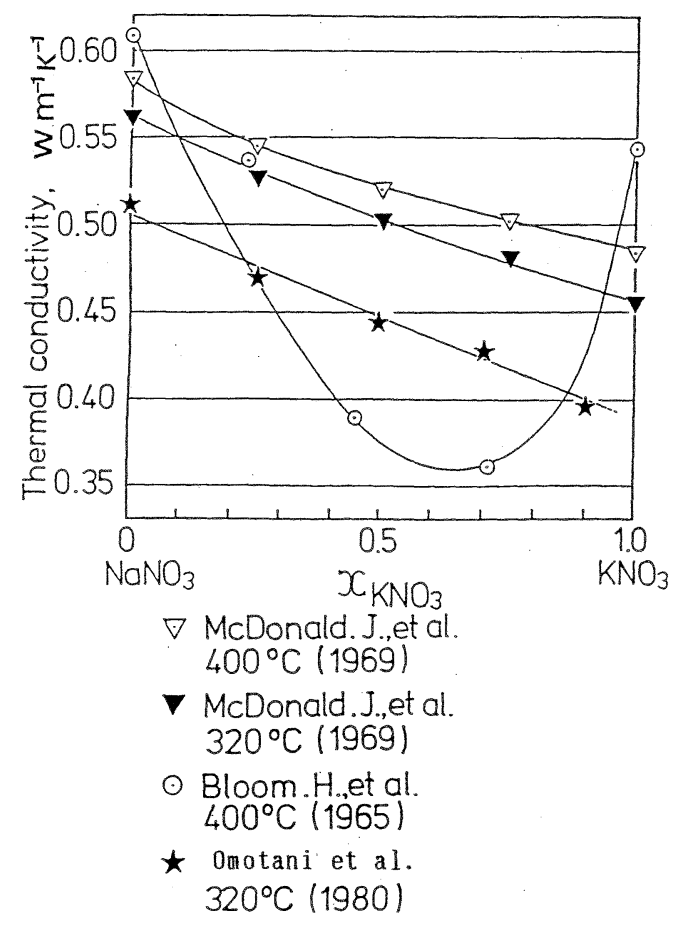

Fig.5 Thermal conductivity of $\mathrm{NaNO}_{3}-\mathrm{KNO}_{3}$ system. Concentration dependence
げている[ 15$]$ 。

Figure 6 に示したのは、工業的な熱媒体と して重要なH T S (high temperaturesalt) の熱伝導 率で、従来のデー夕は、正勾配のもの、强い負勾配の ものなどまちまちであったが、重谷らの結果は、塩化 カリウムや硝酸塩混合物などと同様に、やはりゆるや かな負の勾配をしめしている $\left[\begin{array}{ll}1 & 6\end{array}\right]$ 。

液体金属は、その熱伝尊率の值が非常に大きくて温 度差が生じにくいうえ、動粘性率が小さく对流を起こ し易いので、測定は難しい。アルカリ金属の热伝導率 の例を Fig．7に示すように、同系の物筫であって も、過去の測定例は温度依存性が正負に分かれている [ 17 7 ]。

\section{4 高温融体の粘性率}

粘性率は液体の棈造を解きあかす鍵となる物性值で あるが、同時にまた、設計や流動解析、あるいはプラ ントのシステム制御など、多くの工学的応用で最も必 要な情報である。各種の高温の液体のうちでは、最も 系統的に研究され、データベースも比較的完備してい るのは溶融塩である。これまで長年にわたり、米国の Janzを中心としたグループの活動によって、データべ 一スつくりや標準值の提案が䌇けられてきた[ $\left.\begin{array}{ll}1 & 8\end{array}\right]$ [ $\left.\begin{array}{ll}1 & 9\end{array}\right]$ 。そして多数のまとまった報告が主としてJ. Phys.Chem.Reference Data誌に発表された。この成果 は非常に大部で立派なものであるが、標準データに関 する限りは、物唄数でも物性值数でも、まだまだ不十 分な現状にある。

粘性率については、硝酸カリウムと塩化ナトリウム だけはJanzらによる標準データが定められている。そ の意味で最もよく調べられているはずの溶融塩化ナト

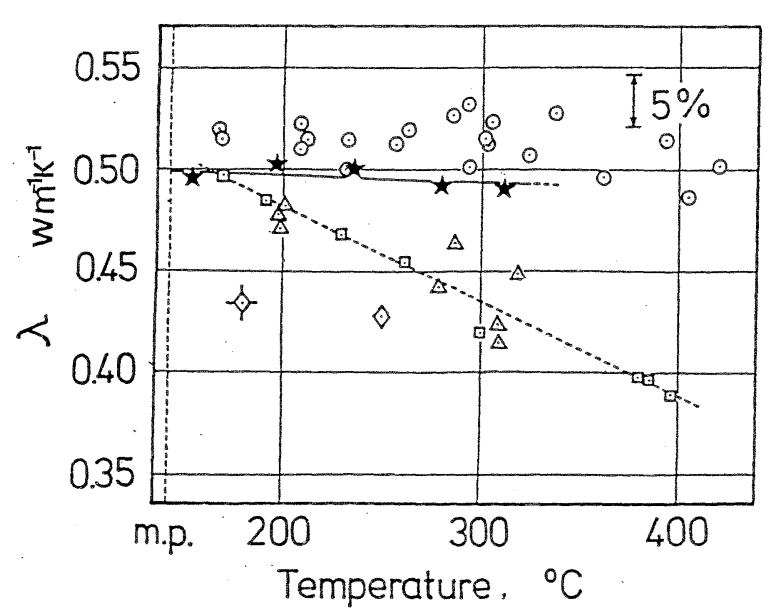

Fig. 6 Thermal conductivity of HTS
\& Vargaftik (1952)

$\diamond$ Vargaftik (1958)

$\square$ Turnbull (1961)

$\triangle$ Cooke (1973)

$\odot$ Kawamura et al.

(1977)

Omotani et al.

(1980) 


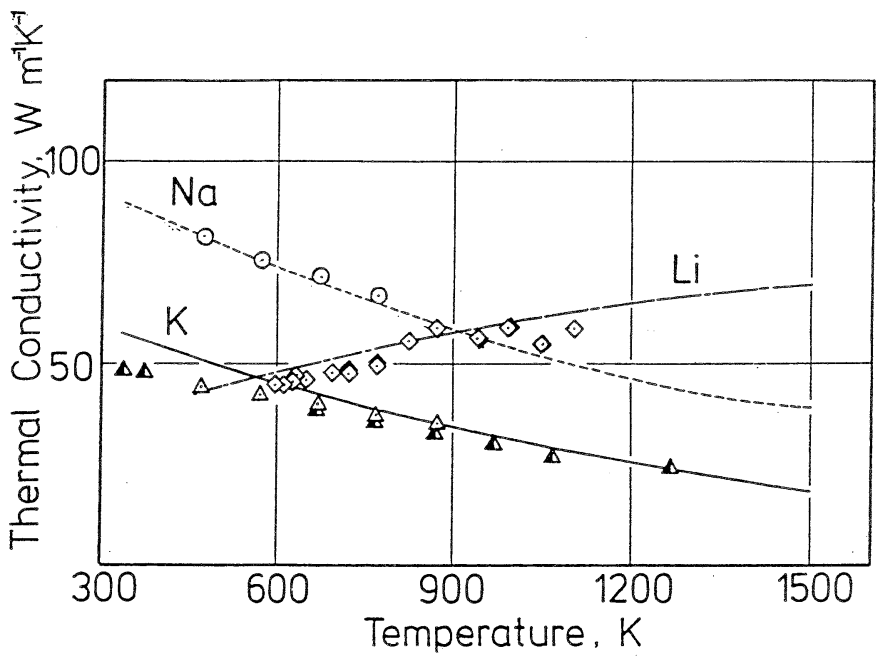

• Li Cooke et al. (1964)

$\odot \mathrm{Na}$ Ewing et al. (1952)

$\triangle K$ Ewing et al.(1952)

$\Delta K$ Shpilrain et al.(1969)

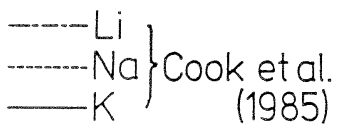

Fig.7 Thermal conductivity of molten alkali metals

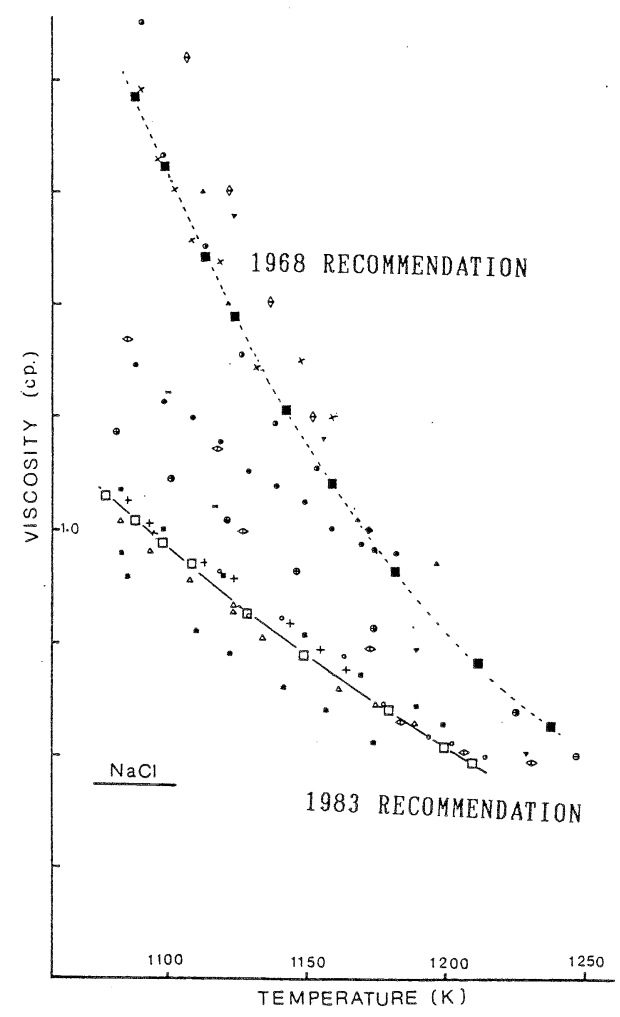

Fig. 8 Viscosity of sodium chloride (situation in 1983)

(drawn by J.Janz)
リウムの粘性率を F i g ～８と F i g .9 で見てみよ う。まずFig，8であるが、ここには1983年の MS D C (米国の溶虽塩データセンター) による新推 桨值が発表される以前の状態が示されている[20]。 図中には 1968 年のM S D C の旧推奖値が示されて おり、Fig，9に示す新推势值と50\%にものぼる 大差がある。粘性率のような基本物性值で、しかも国 際的な推势值が $50 \%$ も変更されるということは、大 変なことといわねばならない。F i g . 9では、19 75 年以後の新しいデータだけを拡大して示したにも かかわらす、標準物質としては、まだ洴足すべき状態 ではない。

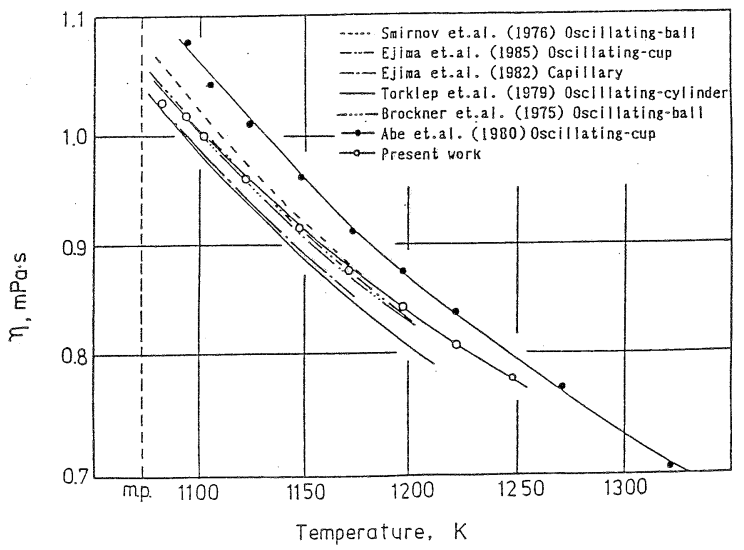

Fig.9 Viscosity of sodium chloride (comparison of recent data) 


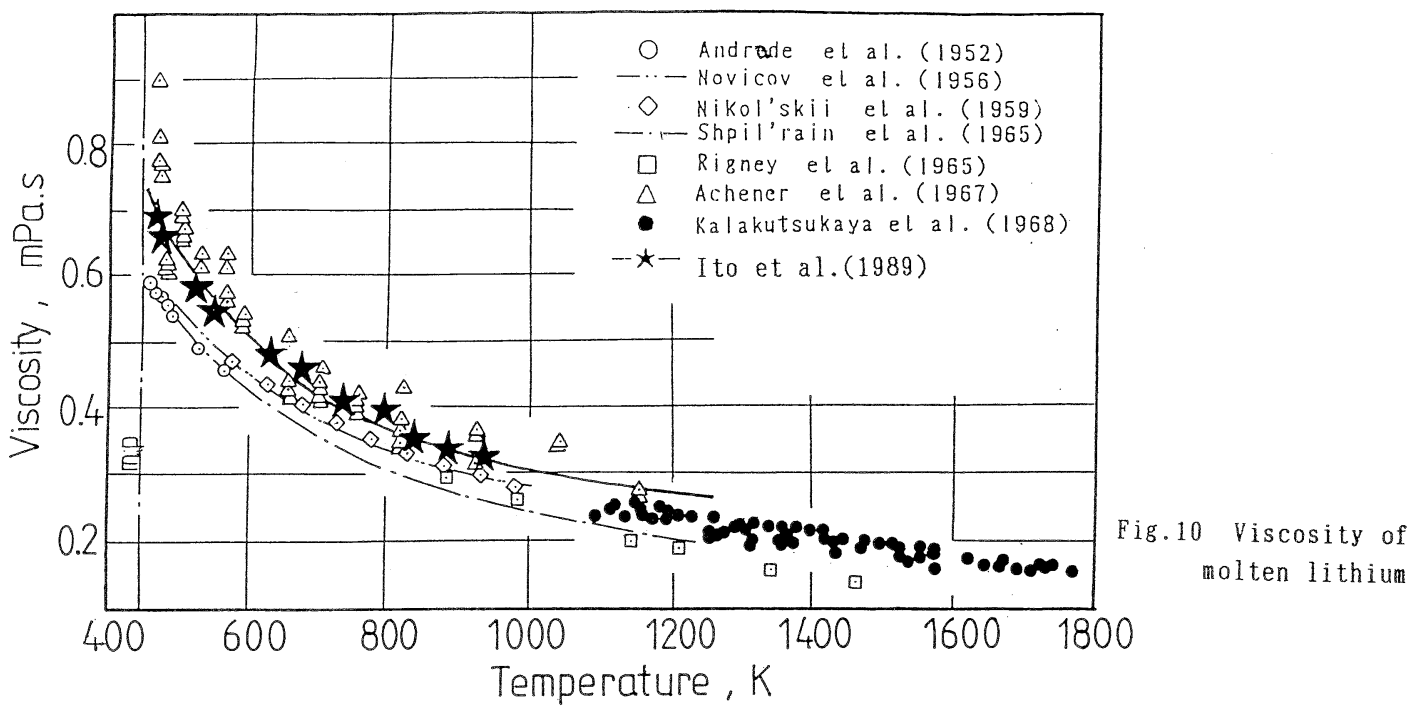

液体金属のデー夕の現状はもっと不備である。例え ば、リチウムの粘性率を見ると、F i g ，10のよう に、過去のテータは $30-40 \%$ にのぼる範囲にバラ ついている。ただリチウムの場合には、その不一致の 原因がある程度明らかにされた［２１］。これらの原 因は、他の高温融体の場合にも示啳するところが大き いので、要点を述べておくことにする。ます第一に、 リチウムについてのいくつかの測定例では、振動法の 不適切な計算式が使われていることがわかった。特に 振動法では粘性率を算出する理諭式の選択が問題で、 計算機が広く用いられるようになる以前に用いられた 簡易な近似式が、いまだに用いられることがある。第 二の原因としては、いくつかの測定例では、試料との 反応が疑われる容器材料が使われていた。容器との反
応は、高温における経過時間に従って徐々に表れるの で、ある程度長期にわたって測定を繰り返さないと発 見するのがむすかしい。

データの収集やレビューとしては、アルカリ金属に ついてはOhseのレビュー[7] に詳しく扱われている。

半導体融体については、1960年代にり連を中心 としてデータが発表されているが、信頼性に疑問のあ るものが多い。最近の見るべき研究には、㭪本、日比 谷によるガリウムひ素の測定 [ $\left.\begin{array}{ll}2 & 2\end{array}\right]$ などがある。こ れらの研究では、融点近くで粘性率がアレニウス曲線 からはずれる結果を示しており、他の研究によっても この種の物質が、液体状態においてある構造をもつこ とが示唆されている。スラグ等については、学振の 委員会による精力的な調查［1］［2］がある。国際

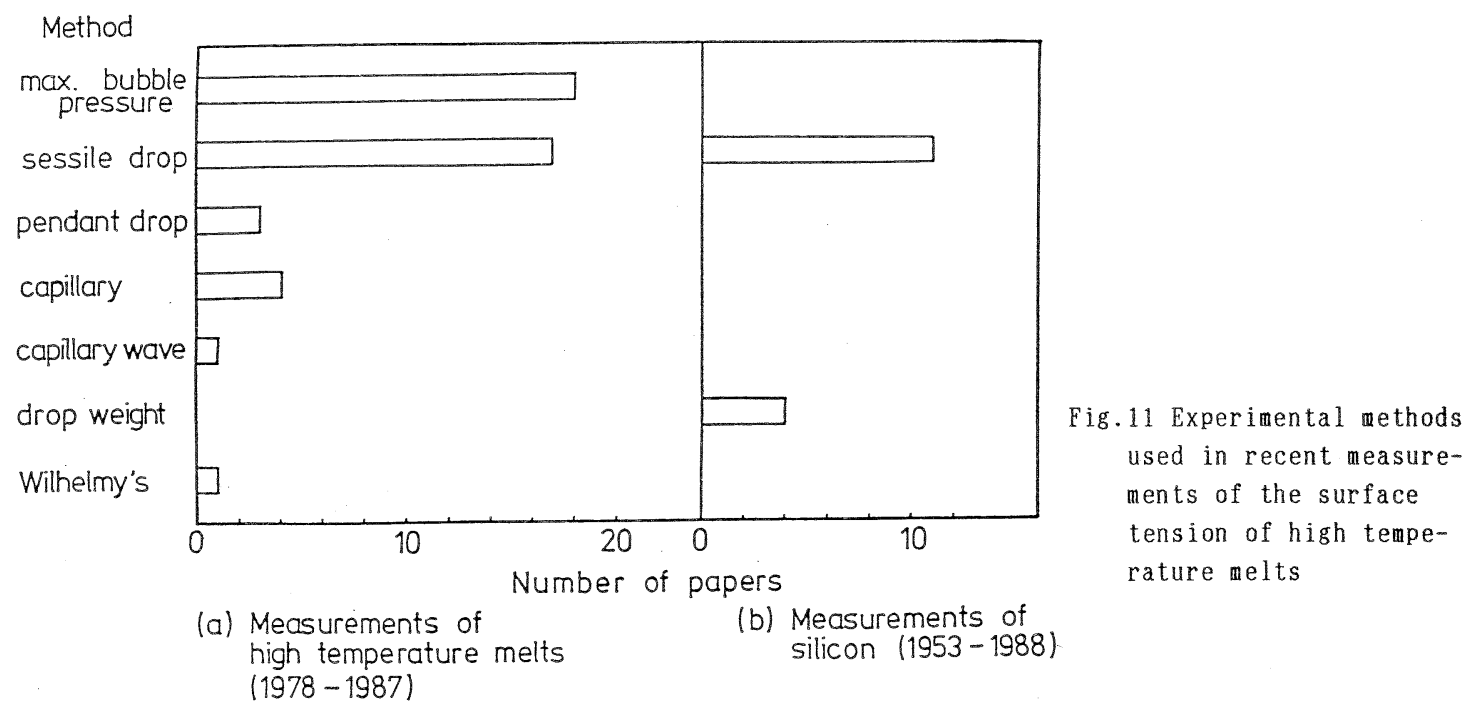


的なデータの標準化などは行われていないようである。 現在のところ、高温液体の粘性率については、その まますぐ使えるような市販の測定装置はない。研究者 は装置設計も自分で行うことになるが、その確漶に用 いるべき標準データが十分でないことが問題である。

\section{5. 表面張力}

高温融体の表面張力は、最近、多くの新しい科学技 術分野において重要な情報として求められている。例 えば単結晶製造では、融体挙動やマランゴー二対流の 解析に必要であり、高温燃料電池における溶融塩の学 動、直接接触伝熱における液滴や気泡の挙動、動力プ ラントの固体材料の溶融破断による事故解析等、物質 の種類も温度範囲も広い。

高温では、液体は容器材料やまわりのガスと反応し 易く、純粋に保つのが難しい。そして不純物の影䜾を 最も敏感に受けるのが表面張力である。常温付近で使 われるいろいろな測定方法も、高温の液体に適用でき るものはわすかしかなく、それぞれ問題点も多い。

澌定方法については、F i g . 11 に示すように、 同じような高温融体間でも、物質ごとに使われる方法 に違いがある。これは比較的最近の諸研究において使 われた方法を、シリコン（b）とそれ以外（a）の融 体とにわけて頻度を調べたもので、普通の融体の測定 で最も多く使われる最大泡圧法が、シリコンには使わ れない。最大泡圧法の問題点は、接触するガスの作用 が末知であることである。Hardy [ l 23 3 $]$ はシリコンに ついて、Fig.12のように周囲の酸素の含有量に よって大きく左右されることを報告している。このよ うな点も、シリコンの表面張力データが F i g . 13 のようにバラついている理由かとも考えられる。やは りよく用いられる静滴法でも、接触する固体表面との

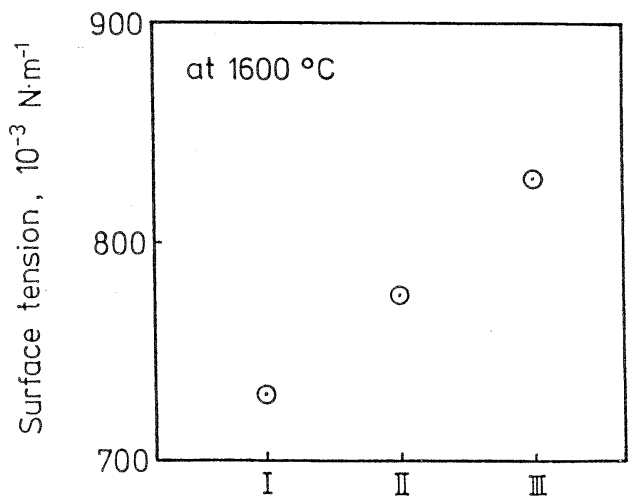

Fig.12 Surface tension of silicone Effect of different concentration of oxygen

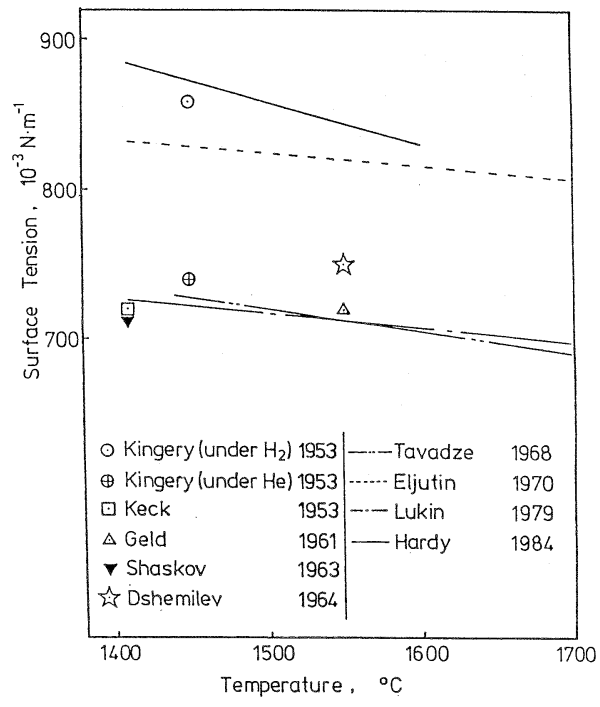

Fig.13 Surface tension of silicone

柖互作用が問題で、Fi g.140例にも示すように、 同し静滴法で測ったゲルマニウムの表面張力でも、グ ラファイト基盤上で測ったときと、石英基盤上で測っ たときでは、温度依存性が正負に分かれる [ 2 4 ] 。 接势するカスや基盤との相互作用を考えると、高温融 体に対して、自由表面を観測する表面波法［２２５］な どの開発が必要である。

高温の液体の表面張力に関するレビューまたはサ一 ベイとしては、アルカリ金属 [26]、液体金属 [2]、 スラグ［1］［2］などがある。

\section{6. 高温の液体の熱物性のこれからの課題}

高温融体の搆造や理論研究はこれからの興味樑い課 題であるが、話を熱物性值にかぎれば、次のようなこ

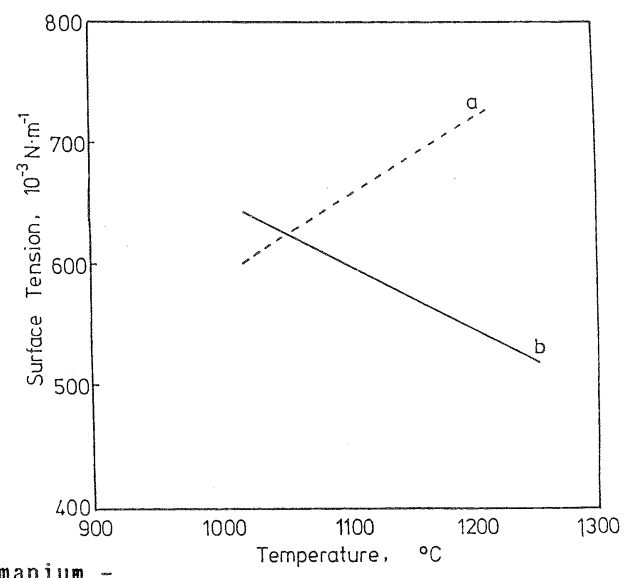

Fig.14 Surface tension of germanium Effect of different contact surface. $a$ : on graphite, $b$ : on quartz 
とが考えられる。

高温融体の熱物性值についての問題は、その熱物性 值デー夕が不足しているだけでなく、現在入手可能な デー夕相互間に、大きな不一致がみられることである。 この不一致は、単に大きさの違いにとどまらす、温度 依存性が逆であったりする。したがって、緊急の課題 は、第一に $1500{ }^{\circ} \mathrm{C}$ 以上で使える倍頼度の高い測定 法を開発すること、第二に小数のキ一物㰓についての 標隼デー夕を定めることであろう。それらの新湖定法 としては、次の条件を備えることが望ましい。

(1) 非定常測定、特にサブセコンドからサブミ

リセコンドの測定が可能なこと

(2) 非接触測定が可能なこと

（3）腐食性の强い液体に適用できること ま亡、物性の種類としてはどれも重要ではあるが、強 いていえば、熱伝導率および表面張力の研究などが特 に緊急であるように感ぜられる。

涀存するデータの評価・選别と、データベース作り なども推進しなくてはならない。

\section{参考文献}

[1] 日本学術振顝会第 140 委員会” 溶融金属・合 金、溶融スラグ、溶融塩の物理化学的性䫓に関 する文献集”、（昭5 7)。

[2]”エレクトロスラグ再溶解スラグの性筫”（日 本鉄銅協会、1979)。

[3]”溶鉄・溶さいの物性值便覧”（日本鉄銅協会、 昭 47 )。

[4]”古川和男、大野英雄編; 無機融体の物性值第 1 集、 L i F - B e F 2 系溶融塩 (Flibe)" （日本原子力情報センター、1980）。

[5]”無機融体の物性值第 2 集、 $\mathrm{KNO}_{3}+\mathrm{NaNO}_{2}+\mathrm{NaNO} 3$ 系溶融塩”（日本原子力情報センター、1988）。

[6]”高温融体の熱物性計測に関する研究”平成元 年度科研費補助金紷合 $\mathrm{A}$ 研究成果報告書”（代 表者長島昭)。

[ 7 ] R.W.Ohse(ed.); "Handbook of Thermodynamic and Transport Properties of Alkali Metals, (Blackwell, Oxford, 1985).

[8]尾添紘之、丸尾英司、松尾浩; 化学工学協会第 54 年会講演要旨集、( 1989 ).

[9] 中村新、日比谷孟俊、横田孝夫、山本文雄 ; 機 械学会熱工学講演会講演概要集（1989）9。

[ 10 l $]$ 中沢巨樹、赤堀正憲、長坂雄次、長島昭、機 械学会論文集、56(1990)245/252.

[ 11 1 ] 荒木信幸、高野義昭; 機械学会熱講要旨集、 (1989).

[ 12 2 ] Y.Nagasaka and A.Nagashima; (to be published).
[ 113 ] J.MaDonald and H.T.Davis; J.Phys.Chem., J.Phys. Chem. , 74(1970)725.

[ 14 4 ] H.Bloom, A.Doroszkowski and S.B.Trickbank; Aust. J.Chem. , 18(1965)1171.

[ 15 ] T.Omotani, Y.Nagasaka and A.Nagashima; Int.J.Thermophys., 3(1982) 17.

[ 16 ] 0motani and A.Nagashima; J.Chem. Eng. Data; $29(1984) 1$.

[ 157 ] A.R.Regel, A.Smirnov and E.V.Shadrichev, Phys.Stat.Sol., (a)5(1971)13.

[ 18 ] A.Nagashima;Appl.Mech.Review, 41(1988)113 /128 の参考文献リストを参炤。

[ 199 ] G.J.Janz; Proc.4 thJap. Symp. Thermophys. Prop., Yokohama, (1983)199.

[ 20 ] G.J.Janz;High Temp.Sci., 19(1985), 173.

[ 251 ] T.Ito,K.Minami and A.Nagashima; Int.J. Thermophys., 10(1989)173/182. .

[ 22 2] 日比谷孟俊、山本文雄、中村新、横田孝夫; 日本マイクログラビテイ応用学会誌、7-2 (1990).

[ 23 ] S.C.Hardy; J.Crystal Growth,69(1984) 456.

[ $\left.\begin{array}{ll}2 & 4\end{array}\right]$ T.P.Koleniskova; Izv.VUZ, Chern. Metal., 9 (1960)14.

[2 5 ] 魚田幸彦、長坂雄次、長島昭; 第 8 回熱物性 シンポジウム講演論文集(1987)203.

[ 26 ] B.C.Allen; Handbook of Thermodynamic and Transport Properties of Alkali Metals, (ed.R.W.ohse), (Blackwell,0xford,1985). $691 / 700$.

[ $\left.\begin{array}{ll}2 & 7\end{array}\right]$ T.Iida and R.L.Guthrie; The Phys.Prop.of Liq. Metals (0xford, 1988).

\section{Thermophysical Properties of High Temperature Liquids}

\author{
Akira Nagashima \\ Keio University \\ Hiyoshi, Yokohama, 223
}

With the extended applications of high temperature liquids in industry and the needs of more sophisticated control of their thermodynamic as well as hydrodynamic conditions, demands of thermophysical properties of high temperature liquids are strong. Present status is briefly reviewed for such thermophysicsl properties as the thermal conductivity, the viscosity and the surface tension of high temperature melts, namely, liquid metals, molten salts and molten semiconductor materials.

(Received on Aug.22, 1990) 